УДК 631.162

L. Seliverstova,

Doctor of Economic Sciences, Professor, Professor of Department

of Finance, Kyiv National University of Trade and Economics, Kyiv

ORCID ID: 0000-0002-2231-0558

N. Losovska,

competitor of a scientific degree, Chernibiv National Technological University, Chernibiv

ORCID ID: 0000-0003-3171-8771

\title{
FEATURES OF THE FORMATION OF BUSINESS SOCIAL RESPONSIBILITY IN UKRAINE
}

\author{
А. С. Селіверстова, \\ А. е. н., професор, професор кафедри фінансів, Київський національний торговельно-економічний університет, м. Київ \\ Н. В. Аосовська, \\ здобувач, Чернігівський національний технологічний університет, м. Чернігів
}

\section{ОСОБ ИИВОСТІ ФОРМУВАННЯ СОЦІААЬНОЇ ВІАПОВІАА ЬЬНОСТІ БІЗНЕСУ В УКРАЇНІ}

The article is devoted to the analysis of peculiarities of formation of business social responsibility. Increasing the level of competition in the domestic market promotes the search for new managerial decisions, one of which is the introduction of social responsibility in the activities of domestic enterprises. An important issue today is the study of the benefits of implementation and effective approaches to the implementation of social responsibility of business for domestic enterprises as an integral part of entrepreneurship in the system of national economy and justification of the benefits of such activities.

The approaches of scientists and international organizations to the concept of social responsibility are researched. The advantages of introduction of business social responsibility in the national practice are determined. The effective approaches to realization of business social responsibility for domestic enterprises are substantiated as an integral part of entrepreneurship in the system of national economy. The components of levels of business social responsibility are systematized.

The concept of business social responsibility is considered. The concept of business social responsibility is effective and tested by international companies as a tool for sustainable development of both society and the country as a whole. Social responsibility is a connecting link between sustainable development of society and the sustainable development of the organization. An important step in its formation is state regulation and support. State policy in the field of social responsibility is an integral part of its systemic development. Such a policy stimulates the dissemination of institutional norms of social responsibility, creates conditions for the business of social investment; it is a series of legislative and additional initiatives aimed at the business community and is realized largely due to the active position of the representatives of society. The necessity of development of effective state policy in the field of social responsibility is emphasized, in this connection the directions of stimulation by the state of development of social programs are highlighted. 
The practical significance of the results obtained is that their application will contribute to the development of the enterprise and the country as a whole, at the expense of the social benefits received from the introduction of social responsibility at domestic enterprises.

Статтю присвячено аналізу особливостей формування соціальної відповідальності бізнесу. Посилення рівня конкуренції на вітчизняному ринку сприяє пошуку нових управлінських рішень, одним із яких є впровадження соціальної відповідальності удіяльність вітчизняних підприємств. Важливим питанням сьогодення є вивчення переваг впровадження та ефективних підходів до реалізації соціальної відповідальності бізнесудля вітчизняних підприємств як невід 'ємної складової підприємництва в системі національної економіки та обгрунтування переваг здійснення такої діяльності.

Досліджено підходи науковців та міжнародних організацій до поняття соціальної відповідальності. Визначено переваги впровадження соціальної відповідальності бізнесу увітчизняну практику. Обгрунтовано ефективні підходи до реалізації соціальної відповідальності бізнесу для вітчизняних підприємств як невід'ємної складової підприємництва в системі національної економіки. Систематизовано складові рівнів соціальної відповідальності бізнесу.

Розглянуто концепцію соціальної відповідальності бізнесу. Концепція соціальної відповідальності бізнесує ефективним та апробованим міжнародними компаніями інструментом забезпечення сталого розвитку як суспільства, так і країни в цілому. Соціальна відповідальність є сполучною ланкою між стійким розвитком суспільства і стійким розвитком організації. Важливим кроком в її становленні є державне регулювання та підтримка. Державна політика в сфері соціальної відповідальності - невід'ємний елемент ії системного розвитку. Така політика стимулює поширення інституційних норм соціальної відповідальності, створює умови для здійснення бізнесом соціальних інвестицій, є рядом спрямованих на бізнес-співтовариство законодавчих і додаткових ініціатив і реалізується багато в чому внаслідок активної позиції представників суспільства. Наголошено на необхідності розробки ефективної державної політики в сфері соціальної відповідальності, у зв'язку з чим виділено напрями стимулювання державою розвиткусоціальних програм.

Практичне значення отриманих результатів полягає у тому, що їх застосування сприятиме розвитку підприємства та країни в цілому, за рахунок отримуваного соціального ефекту від впровадження соціальної відповідальності на вітчизняних підприємствах.

Key words: business social responsibility of, state policy, stimulation, social effect, concept.

Ключові слова: соціальна відповідальність бізнесу, державна політика, стимулювання, соціальний ефокт, концепція.

\section{SETTING OBJECTIVES}

In a context of globalization and constant competition, more and more businesses in developed countries are paying particular attention to socially oriented businesses and sustainable development. At the same time, domestic business is at the stage of implementing such an activity and it is not well informed about the benefits and advantages that can be derived from the implementation of the principles of social responsibility in a context of rapid economic development.

\section{ANALYSIS OF RECENT RESEARCH} AND PUBLICATIONS

The theoretical basis for the study of the foundations of the formation of the business social responsibility is the work of domestic and foreign scientists, in particular, such scholars as M. Albert, D. Bayura, O. Berezin, H. Bowen, A. Williams, V. Vorobey, T. Gorokhov, O Grushnova, L. Denisyuk, V. Dovbnia, I. Zhiglya, F. Kotler, E. Kovalenko, O. Lazarenko, I. Malyk, M. Meskon, T. Savaeva and others.

\section{STRESSING THE PREVIOUSLY UNSETTLED}

\section{PARTS OF THE GENERAL PROBLEM}

In the works of domestic researchers the theoretical approaches are highlighted and universal recommendations are suggested that of ten do not take into account the peculiarities of functioning and the state of the national economy.

Consequently, an important issue of the present is the study of the benefits of implementation and effective 
approaches to implementing social responsibility of business for domestic enterprises as an integral part of entrepreneurship in the system of national economy and justifying the benefits of such activities.

\section{SETTING OBJECTIVES}

The objectives of the study are to comprehensively study the development trends and peculiarities of the formation and functioning of approaches to the business social responsibility in the domestic practice.

\section{PRESENTATION OF THE MAIN RESEARCH MATERIAL}

The development of the business social responsibility plays an important role in the management of modern companies, but in domestic practice it is not used enough. Although social responsibility is a private initiative, it receives considerable development at the expense of stimulation by representatives of society and authorities.

Business social responsibility is a necessity both for owners of enterprises and for workers, consumers of goods and services, business partners, state institutions and society as a whole. The combination of interests of all these parties reflects the need for social responsibility, which aims to achieve social agreement [1, p. 309].

Business social responsibility is multilevel:

1. Provision is made for such obligations as timely payment of wages and taxes, as well as, if possible, the provision of new jobs.

2. Provision of employees with acceptable conditions for work and life: raising their level of qualification, preventive treatment, housing construction, development of social sphere. This type of responsibility was conventionally called "corporate responsibility".

3. Further, charity activities are foreseen. It is necessary to understand who the business is socially responsible for. Since corporate social responsibility subjects are found to be quite a lot, social responsibility can be divided into internal and external. This approach is based on the allocation of social actors who have an interest in the activities of this organization. They include shareholders and employees (the internal environment) and society as a whole, local communities, investors, consumers of products (external environment).

The internal business social responsibility can be attributed to labor safety, salary stability, social support, additional medical and social insurance of employees, development of human resources through curricula and training programs, and assistance to workers in critical situations.

The following can be attributed to the external business social responsibility: sponsorship and corporate charity, environmental protection, interaction with local communities and local authorities, readiness to participate in crisis situations, responsibility to consumers of goods and services (production of quality goods).

It should be emphasized that, in addition to the theoretical economic developments in this area, the international organizations such as the UN, the EU and the OECD, which cooperate closely in this field, have made a major contribution to the development and establishment of social responsibility as the basis for the implementation of business activities around the world. It is the UN that develops the Code of Conduct for Transnational Companies (1980) and the UN Global Compact (2000) [2]. In addition, the first international standard "Social Responsibility 8000 " was developed internationally, which complies with the principles of the Conventions of the International Labor Organization, the Universal Declaration of Human Rights, the UN Convention on the Rights of the Child and defines the ethical criteria for the production of goods and the provision of services [3; 4].

And in 2010, the international standard ISO 26000 "Social Responsibility Manual", developed by the ISO / WG SR working group on the basis of SA 8000, is the basis for CSR business and public sector sectors [5].

The assessment of the role of social responsibility in the development of society provides a systematic approach to it, which includes the micro level (the practice of companies with universal grounds) and the macro level (business social responsibility as an institution having a number of functions and requirements), and the institutional development of the business social responsibility allows us to talk about its systemic nature.

There is currently no single understanding of social responsibility. In most cases, social responsibility is defined as the activity of business, aimed at solving social problems of the labor collective and the population, which goes beyond the mandatory provisions of the legislation. However, in all existing definitions, something general can be singled out, namely, at the very basic level, socially responsible behavior means refraining from harm to the surrounding world and promoting social development in the country.

Social responsibility is formed as a formal process of declaring public utility, aimed at creating an image and commitment from society. At the same time, the low level of state intervention in the process of development of social responsibility is combined with a high level of informal relations and the lack of generally accepted standards and mechanisms for the implementation of social responsibility [7, p. 46].

In recent years, the concept of corporate social responsibility has become widespread in Ukraine. That is a system of social relations with interested groups (stakeholders), interaction with the state in solving social problems. The concept of corporate social responsibility is effective and tested by international companies as a tool for sustainable development of both society and the country as a whole. Realization of the concept of business social responsibility involves not only the development of a certain social strategy, but also the creation of a control system, feedback, infrastructure.

The effectiveness of the concept of corporate social responsibility depends on the creation by the state of incentives that promote profitable cooperation in the areas of improving the company's image, sustainability and competitiveness.

The importance of developing the business social responsibility is to minimize the negative consequences of their production activities on companies, solve global and local development problems, and shape the atmosphere of predictability, trust and common values in society. Business through social responsibility becomes more economically and socially sustainable, gets an opportunity to increase its intangible assets. 
Social responsibility is a connecting link between sustainable development of society and the sustainable development of the organization. The mechanisms of social responsibility serve as the basis of innovation culture. The organization's social responsibility involves controlling the effects and reimbursement of damage to the environment, as well as voluntary commitments to ensure the welfare and development of society.

Company executives are primarily responsible to interested parties for the effective management of company resources. Responsibility, in this case, involves profits and the development of the organization. At the same time, business is responsible to society: the social responsibility of business involves promoting sustainable development, improving the environment and improving the welfare of society [8, p. 56].

An important issue in the sense of social responsibility is whether it should be the subject of public regulation or it undermines the very basis of this idea. At the same time, the question concerns state regulation, since certain selfregulation takes place within the framework of various types of business structures and employers and international organizations.

It is clear that the state must provide the people all the important social, material, and other necessary benefits for its effective development, but as it turns out in reality, it is not so simple as it seems at first glance, in this case social responsibility should be understood as the relations of the more powerful layers of society with less power and those that need protection and support.

The state in its essence plays the role of some regulator in market relations because of the imperfection of the latter, it creates the mechanisms of market management. Formation of the state budget at the expense of the funds received from taxes, customs duties and other sources of income, is to solve a number of problems, including social ones. State developed control mechanisms on the issue, which is the task of social policy, but the state and its laws would be perfect as they are not able to regulate all possible aspects of the business. If control of the formal parties can still be established, then imposing a benevolent attitude towards the outside world is impossible. Therefore, it is so important to encourage the efforts of domestic companies to establish a culture of production, to implement the principles of social ethics, to develop the best ways to develop activities.

Modern states realize the benefits of participating business units in social policy, because, as a result of the distribution of social responsibility in society efficiency debugging state increases - low living standards, high unemployment, social insecurity $[9$, p. 13], which is an important argument for introducing social responsibility at domestic enterprises.

Promotion of social responsibility does not mean entrepreneurs involved in social programs for "adequate remuneration" - the creation of favorable conditions or, between business and the state relevant auction on the preferences provided by certain actions. An example of effective cooperation can be the conclusion of agreements between business entities and government bodies. Its subject matter may be a wage - setting of the level and timing of payments, different social investments, joint maintenance of social services in rural areas and others. Such agreements have a positive effect on the development of the regional economy, the creation of new jobs, and the increase of wages [10].

Public incentives should include forecasting, budgeting, licensing, financing, taxation, lending, administration, supervision, control and accounting.

The main directions of stimulation by the state of development of social programs should be:

- creation of cooperation programs in the social sphere between the state and business structures;

- regulatory consolidation of social responsibility of enterprises of the private sector;

- creation of a system of benefits for employers who form similar programs;

- state aid for the formation of social programs;

- development of stimulating legislation;

- introduction of compulsory social reporting for a number of enterprises belonging to certain industries.

The state can use its resources to form partnerships with business in the social sphere, while the specific roles may be different. Many experts and politicians believe that the most important tool for solving social problems should be the further deepening of democracy, which is associated with the idea of partnership and participation. At the same time, the partnership is defined as an organizational system for decision-making and its implementation, mobilizing a coalition of interests around a common problem. The role of the state in these conditions is to develop cooperation and to ensure dialogue between stakeholders in the circle of their interests.

Although the business social responsibility is formally identified with voluntary non-mandatory social business initiatives, in practice social responsibility can not be considered separately from state policy.

The business social responsibility has emerged both at the national and international levels, as a response to the shortcomings and restrictions of state regulation, largely reflecting the "deficit of the state." This explains why it has recently become so widespread and researched in European countries, where, in some respects, the role of the state has diminished and the importance of the market and business has increased. The state's problems help to understand the growing importance of social responsibility, reflecting the shortcomings of existing legislation on business regulation, both nationally and internationally.

\section{CONCLUSIONS}

As in Ukraine, the process of introducing CSR is at an advanced stage, there is a lack of understanding of the integrity of the concept, tested practices and their usefulness. The business social responsibility remains focused on the closest stakeholder - the state, owners, staff and organizations that represent it. A wider range of stakeholders - local communities, territorial communities, regions, suppliers, consumers are virtually excluded from this process. This is largely due to the fact that in Ukraine, the main drivers of the process of implementing social responsibility are still a small number of large companies that, by conducting a primary public offering of shares on international stock exchanges, are 
forced to accept the terms of potential shareholders, thereby increasing the value of their shares. These actions at this stage are mostly unsystematic and unprofessional.

Implementation of business social responsibility in Ukraine is necessary at this stage of development of the country. An important step in its formation is state regulation and support. State policy in the field of social responsibility is an integral part of its systemic development. Such a policy stimulates the dissemination of institutional norms of social responsibility, creates conditions for the business of social investment; it is a series of legislative and additional initiatives aimed at the business community and is realized largely due to the active position of the representatives of society.

References:

1. Seliverstova, L.S. (2015), "Formation of the strategy of corporate social responsibility", Actual problems of the economy, vol. 7, pp. 309-314.

2. UN Global Compact. Ministry of Social Policy of Ukraine (2008), "Social insurance and partnership", [Online], available at: http://www.mlsp.gov.ua/labour/ control/uk/publish / article \%3Bjsessionid=07E30561B5BF4DDE28B50412BE5BA03D?Art_id=88867\&cat_id=34940 (Accessed 10 July 2019).

3. Gunyaeva, N. (2004), "International standards in the field of social responsibility", Standards and quality, vol. 10 , pp. $61-65$.

4. Mamatov, T. (2010), "International standards in the field of social responsibility: the mechanism of adaptation for the bodies of state control of Ukraine", Bulletin of the Dnipropetrovsk Regional Institute of Public Administration, pp. $51-53$.

5. International Organization for Standardization (2019), "Social Responsibility Guide ISO /DIS 26000/. Guidance on social responsibility", [Online], available at: isotc.iso.org (Accessed 6 July 2019).

6. Smachilo, V.V. and Balyaba, V.O. (2015), "Assessment of social responsibility of construction enterprises. Economics: realities of time", Scientific Journal, [Online], vol.6 (22), pp. 162-169, available at: http://economics.opu.ua/files/archive/2015/n6.html (Accessed 24 June 2019).

7. Shinkarenko, O.N. (2013), "Corporate social responsibility and social (non-financial) responsibility", Personnel of the enterprise, vol. 7, pp. 43-56.

8. Vasilenko, E. (2006), "Social responsibility of business: world experience and Russian realities", Power, vol. 1. pp. $54-60$.

9. Kurbatova, M.V. (2005), "Social responsibility of Russian business", IVF, vol. 10, pp. 13.

10. Tyutin, D.V. (2014), "Evolution of a new state administration: the logic of efficiency, effectiveness and management of public values", Theory and practice of social development, vol. 5, [Online], available at: http:// www.teoria-practica.ru/rus/files/archiv_zhurnala/ 2014/5/economy/ututin.pdf (Accessed 10 July 2019).

\section{Література:}

1. Селіверстова Л.С. Формування стратегії корпоративної соціальної відповідальності. Актуальні проблеми економіки. 2015. №7. С. 309-314.
2. Глобальний договір ООН [Електронний ресурс]. Міністерство соціальної політики України. Соціальне страхування та партнерство. 2008. URL: http:// www.mlsp.gov.ua/labour/control/uk/publish / article \%3Bjsessionid=07E3 0561B5BF4DDE28B50412BE5BA03D?art_id $=88867 \&$ cat_id $=34940$

3. Гуняєва Н. Міжнародні стандарти в галузі соціальної відповідальності. Стандарти та якість. 2004. № 10. С. 61-65.

4. Маматов Т. Міжнародні стандарти в області соціальної відповідальності: механізм адаптації для органів державного контролю України. Вісник Дніпропетровського регіонального інституту державного управління. 2010. С. 51-53.

5. Керівництво з соціальної відповідальності ISO/ DIS 26000 / Міжнародна організація стандартизації: Guidance on social responsibility. URL: isotc.iso.org

6. Смачило В.В., Баляба В.О. Оцінка соціальної відповідальності будівельних підприємств. Економіка: реалії часу. Науковийжурнал. 2015. № 6 (22). С. 162169. URL: http://economics.opu.ua /files/archive/ 2015/n6.html

7. Шинкаренко О.Н. Корпоративная социальная ответственность и социальная (нефинансовая) ответственность. Кадры предприятия. 2013. № 7. С. 43-56.

8. ВасиленкоЕ. Социальная ответственность бизнеса: мировой опыт и российские реали. Власть. 2006. № 1. С. $54-60$.

9. Курбатова, М.В. Социальная ответственность российского бизнеса. ЭКО. 2005. № 10. С. 13.

10. Тютин Д.В. Эволюция нового государственного управления: логика эффективности, результативности и менеджмента публичных ценностей. Теория и практика общественного развития. 2014. № 5. URL: http:// www.teoria-practica.ru/rus/files/arhiv_zhurnala/2014 /5/ekonomika/tyutin.pdf

Стаття надійшла до редакчї 11.07.2019 p.

\section{www. dy.nayka.com.ua}

Електронне фахове видання

\section{ДЕРЖАВНЕЕУУПРАВЛПННЯ удосконалення та розвиток}

\section{Виходить 12 разів на рік}

$$
\begin{aligned}
& \text { Видання включено до переліку } \\
& \text { наукових фахових видань України } \\
& \text { з ДЕРЖАВного упРАВлІння } \\
& \text { e-mail: economy_2008@ukr.net } \\
& \text { тел.: (044) 223-26-28 } \\
& \text { (044) 458-10-73 }
\end{aligned}
$$

